\title{
RISALAH|
}

DOI: $10.24014 /$ jdr.v31i2.11255

\section{SYMBOLISM AND ISLAMIC VALUES IN STUDENTS' REOG STAGE AT MUHARAM CELEBRATION}

\author{
Muslih Aris Handayani ${ }^{1}$ \\ ${ }^{1}$ State Institue for Islamic Studies Ponorogo \\ Email: az.muslih197@gmail.com
}

\section{Kata kunci}

Simbol, makna,

tanda, Muharam

\section{Keywords}

Symbols, meanings, signs, Muharam

\begin{abstract}
Abstrak
Tanda, simbol, dan makna merupakan unsur penting dalam interaksi antarmanusia. Penelitian ini bertujuan untuk mengungkapkan bagaimana tanda-tanda, simbol, dan makna terkait dan dapat digunakan untuk menggambarkan hubungan antara siswa dalam pementasan budaya Reog yang menampilkan nilai-nilai Islam. Hasil penelitian menunjukkan bahwa interaksi antarpemain muslim di pentas Reog membentuk kebersamaan, pengorbanan jiwa, perjuangan, dan persahabatan. Hasil penelitian tanda, simbol, dan makna dalam hubungan di antara mahasiswa Islam dalam pementasan Reog menunjukkan bahwa komunikasi adalah proses penandaan dan penandaan pada tanda-tanda untuk mendapatkan pemahaman bersama tentang makna yang melibatkan kreativitas manusia dalam produksi, pertukaran, dan proses pemaknaan dari tanda-tanda dan simbol. Nilai-nilai keislaman mahasiswa dalam pentas Reog Muharam adalah kepemimpinan, kebersamaan, saling menghormati serta sarana silaturrahmi umat Islam masyarakat Ponorogo.
\end{abstract}

\begin{abstract}
Signs, symbols, and meanings are important elements in human interaction. This research aims to reveal how the signs, symbols, and meanings related and can be used to describe the relationship among students in Reog culture staging. The results of the study showed that interaction between muslim's players on the Reog stage forms togetherness, soul sacrifice, struggle, and friendship. This research of signs, symbols, and meanings in the relationship among Islamic students in Reog staging can be obtained that communication is the process of tagging and signification on signs to obtain a mutual understanding of meaning that involves human creativity in the production, exchange, and meaning process of the signs and symbols. The islamic values of students in Reog Muharam stage are leadership, togetherness, mutual respect and the means of silaturrahmi of muslim's community in Ponorogo.
\end{abstract}

\section{Introduction}

Culture is the identity of a region. With culture, the area is widely known by the world community. In addition to regional identity, culture, especially integrated with Islam, becomes a means of da'wah. Islamic da'wah is increasingly accepted by the community if it is able to package regional values with Islamic values. Student's Reog 
performance is a means of communicating and spreading the values of culture and Islam. Appearance, student behavior during the performance of Reog at Muharam in addition to communicate it is also a means of Islamic da'wah.

Human beings are social creatures that are always creative to create signs and symbols in the relationship among humans. With the signs and symbols they created, people made social deals on the symbols and signs. With this creativity, the signs, symbols, and meanings that humans created are always evolving. Lefebvre reminds us that society is neither pure structure nor pure practice, but a dialectic of social structures and human practices. In respect to communication this means that communication is neither linguistic structures nor individual speech acts, but a dynamic, complex production process, the creates and re-creates semiotic and social structures as well as individual consciousness and actions (Fuchs, 2019).

Communication histories improved by replacing tables of successive revolutions with discussions of changing assemblages of social agents and technical artifacts affecting certain societies differently at different times (Bourdon, 2018). In communication and social change-related work is important to understand the context (Thomas, 2020). The communication strategies remained similar, with both players competing to create and occupy the image of cool in the minds of global consumers, albeit through different communication strategies, paths, and venues, drawing on images, artifacts, and content originating from different media sectors (Sigismondi, 2018). The field of communication research is united by the concept of communication, and divided by diverse conceptions and models of its elements and processes. For decades, the field has debated the relationship between transmission and ritual models of communication, as articulated by Carey (Jensen, 2013).

Students in Reog staging are always creative to interact with each other to understand the behavior of others based on Islamic values of their background. With different objectives and interests in interacting with each other in Reog staging, students behave and look their best in front of others. Their performances are directly or indirectly in Reog staging convey the message to others. Appearance either in the form of clothes worn or behavior in front of others is a sign. A sign of behavior and dress or fashion appearance is a message for others.

In a semiotic study, a muslim Reog player's appearance is a sign for others. A muslim Reog player's appearance is also a symbol in other people. A muslim Reog player's appearance is a sign that conveys a message to others in a semiotic study. The appearance of an attack is also a symbol for others, and the appearance of others is also a symbol for him. In this stage there has been a symbol exchange, and in a symbolic interactionism study, the exchange of symbols implicates the meaning.

In the mind of Herbert Blumer, there is a strong connection between semiotic and symbolic interactionism. When a person is in front of someone else, he has delivered a message about his appearance in the form of signs. His appearance is also a non-verbal 
message that is a symbol, rich about meaning. In the end, a person's appearance in front of others is a sign in the semiotics study and is also a symbol that will be interpreted by others in a symbolic interactionism study. In the context of interpersonal communication, symbolic interactions explain that the mind consists of an internal conversation that reflects the interactions, and that have occurred between someone with others. On the other hand, symbolic interactions perceive that the entire structure and social institutions were created by interactions among people. In addition, a person's behavior is not absolutely determined by events in the past, but it is also done intentionally.

The problem arises as to the relation of meaning, sign, and symbol in the interaction among muslim Reog players. How signs, meanings, and symbols can be used to explain the process of interaction or relationship among muslim Reog players. What are the Islamic values of Islamic students's Reog stage. The various historical communications studies are acquired that the meaning arises from the process of creating symbols and signs. Humans interpret each other with the signs and symbols they create and exchange. With the creation of signs and symbols human being know the intent or purpose of their interaction. Bourdieu argued that these symbols function as "the instruments parexcellence of social integration" (Block, 2013).

This research aims to reveal how the signs, symbols, and meanings related to the relationship among Islamic students in Reog staging at State Institute for Islamic Studies Ponorogo. It discusses about the Islamic values and muslim identity of Islamic students in Reog staging at State Institute for Islamic Studies Ponorogo. The field of potential meanings is constantly changing along with each new constituting relation among people, things, and ideas (Jensen, 2013). As a well-educated community, students interact with each other which they tied by campus culture and Islamic values such as the norms and ethical associations that are orderly, polite, and courteous in campus life or in Reog staging. With communication and Islamic values, students plan their existence in society.

Review or study of the library is a study of previous research that has relevance to the research that will be conducted. The library study is related to the description or critical study of previous research of both aspects of the study type, the theory aspect, and the methodology used. Qualitative research should examine these aspects even though in qualitative research is not required. In various studies, no previous research was exactly the same as the research that someone would do. Previous research related to the study of the relation of signs, symbols, and meanings also Islamic values in interstudent relationships in Reog staging at State Institute for Islamic Studies Ponorogo includes the research of David H. Jenkins (2006) about Predictions in Interpersonal Communication.

The results of Jenkins research says if interpersonal communication wants to develop, then individuals should pay attention to all aspects of communication they do, 
the perception of words, sound, and behaviors and understanding of deep motivational relationships and complex behavioral outcomes. The primary purpose of this study is to study the consequences of differences as a result of communication behavior so that individuals are allowed to accurately predict the outcome. Not many communicators directly predict what results they say or they write, more than that, as well as good planning, although there is no purposing that does not exist, and this is very rare. Not many people concentrate on the consequences of communication they do. By the rate, they assumed the desire, the fact, the occurrence, unexpected and unanticipated influences were lost without being remembered. As most people 'desire is a reality' and why many people 'misunderstand' against them beyond the common understanding of customs. Other communicators may not be able to maintain or recall the outcome or impact of their communication. In general, the research of David H. Jenkins considers that most communicators pay less attention to the impact on the communication he is doing. The research that researchers do more forward aspects of the impact or influence of communication to the ability of meaning process, so that based on the signs and symbols, communication related signs, symbols, and meanings can be well understood (Jenkins 1961).

The research of David Ritchie and Leslie T. Good (1989) Communication as a Symbolic Activity showed that elements of communication were objects of scientific investigation and humanity became the subject of serious debate. In their research, Ritchie and Good discussed about Angus and Lannamann research, Questioning the Institutional Boundaries of U.S. Communication Research: An Epistemelogical Inquiry. Angus and Lannamann describe elements of the field as sub-disciplinary growth around an area of self-contained communication objects and tend to focus on the contents of each field from the boundaries between the fields. They concluded these elements impeded the area of communication studies on effective donations of dialogue that arose about the importance of communication in social processes. As a repetition of the elements in the field and make it relatively important to the social and humanities sciences, Angus and Lannamann filed the definition of the area of communication objects as "the knowledge of a person's meaning that formed in social interactions through media or channels." They distinguish someone from the body to define the latest as a communication channel. This approach reveals the focus of communication studies as a symbolic process of a person's meaning as an object domain.

The Angus and Lannamann proposals have resulted in a serious debate. As a disciplined interpersonal communication that focuses on attitudes, authors seem to focus on a cognitive perspective, and pay attention to the production of messages, recognition, storage, and interpretation as attitudes. They do not recognize the importance of dynamic models of communication that do not require distinction between limited and unlimited communication. The difference with researchers that symbols, signs, and meanings of students interaction in Reog staging are interrelated processes that will be 
able to explain communication or signs, symbols, and processes able to be used as a step to redefine communication.

Research of Daniel K. Stewart (2006) Signs, Symbols, and Meaning showed the difference between signs and symbols on the critical tendency of "meaning". However, as long as the signs and symbols of the slope of the windmills, "meaning" will refer to the physical, and most importantly the communication will emerge at any beginning of the phenomenon of physical sightings. When the natural analysis of communication, it is feasible to distinguish between signs and symbols, but this is not the only one raised. As these terms are found in the literature, a common difference suggests that a sign cannot be outlined in human communication, there are even symbols can be. An example sentence is a symbol that can accommodate the communication process. In some cases it refers to a physical referral. It's a commonly created distinction and this illustrates how the researchers understand and pay attention.

On the other hand it is said that referring to this position, most interest in the sentence as a symbol of something, action, quality, relationships, and the other is narrowing of understanding. When the common difference between signs and symbols is expressed with real then this emphasis is less precise on communication research by eliminating the main points that the symbol relates to meaning. When this is used to describe the process of communication, the behavior of the symbols as the main possibility of emphasis of the intended meaning (Stewart, 1966). But when the analysis of signs and symbols concludes meaning as physical something then it is the opposite. The difference with researchers that there is a strong connection between signs, symbols, and meanings. Signs can communicate itself because it interacts with the value of human consciousness. The process of explaining communication begins with signs phenomenon. Symbols do not mean without beginning with the phenomenon of signs.

Andrea Gallant (2014) in Symbolic Interaction and Development of Women Leaders in Higher Education, re-examined the issue of the under representation of women in Higher Education (HE) leadership is a persistent global phenomenon. Eight women aspiring to leadership were invited to participate in semi structured interviews after attending a leadership program specifically designed to enhance their leadership prospects. Analysis indicated that ambiguities and contradiction that surround notion of leadership, in particular how the participants position themselves and are positioned in their workplace. This was evidenced by the meaning they attributed to recognizing a leader, interaction with existing leadership, and speculation regarding their leadership capacity. Gendered notion were apparent in their constructed meaning. Similarity attraction was also evident, with men being observed as "paying it forward", therefore facilitating promotion. Formal leadership training was advocated rather than experiential processes.

Lionel Wee, examines three particular cases taken from the history of Singapore's language policy. In the first situation, the policy remains largely unchanged varying 
only in its lexical and textual realizations, in the second, performances in the service of asset of ideologies give rise to potentially serious problem, and in the third, the material consequences of implementing the ideologies led to changes in the ideologies themselves. By drawing on recent theoretical developments in the study of languages ideologies Lionel Wee shows how attention to the sitedness of language ideologies can help provide greater specification and appreciate on of the interactional processes by which the ideologies are instantiated (Wee, 2006).

Lisa Sulistyaning Kencanasari in her research "Warok Dalam Sejarah Kesenian Reog Ponorogo: Perspektif Eksistensialisme (Warok in History of Reog Ponorogo: Existensialism Perspective)", talked about Warok as one of Reog Ponorogo performance elements contains a philosophical value. In the history of Reog, the figure of Warok is a leader personality who is willing to sacrifice himself for the sake of publicneeds rather than himself or his group. The struggling value that is a role model for national youthrelates to morality. Warok assumed that policies of the king which is influenced by his wife (the queen) harm public needs so that the problem must be overcome soon. The emphasize of this research is the value of bravery and willing to struggle for public needs which is deeply rooted in Warok's soul regarding the unity and welfare of their kingdom. Walking over the truth and public needs is one of the principals of Warok in guarding the unity of their kingdom although they have to fight against their own king. Warok use the Reog performance as a cynicism aimed to the king. They never doubt their decision and action so that it could be a guidance for national morality concept of Indonesia (Kencanasari, 2019).

From the above researchs show that human social interactions either at a verbal level in speech or utterance as well as the appearance of communicators in front of other communicators are depicted separately. In general, research David H. Jenkins considers that most communicators pay less attention to the impact or on the communication he does. The research of David Ritchie and Leslie T. Good reveals that Angus and Lannaman filed a regional definition of communication objects as "the knowledge of a person's meaning that is formed in social interactions through media or channels". While research on Daniel K. Stewart shows on communication research, one finds the distinction between signs and symbols on the critical tendency of "meaning". Andrea Gallant indicated that ambiguities and contradiction that surround notion of leadership, in particular how the participants position themselves and are positioned in their workplace. And the last, Lionel Wee shows how attention to the sitedness of language ideologies can help provide greater specification and appreciation of the interactional processes by which the ideologies are instantiated. This visual below indicate theoretical framework of this article. 


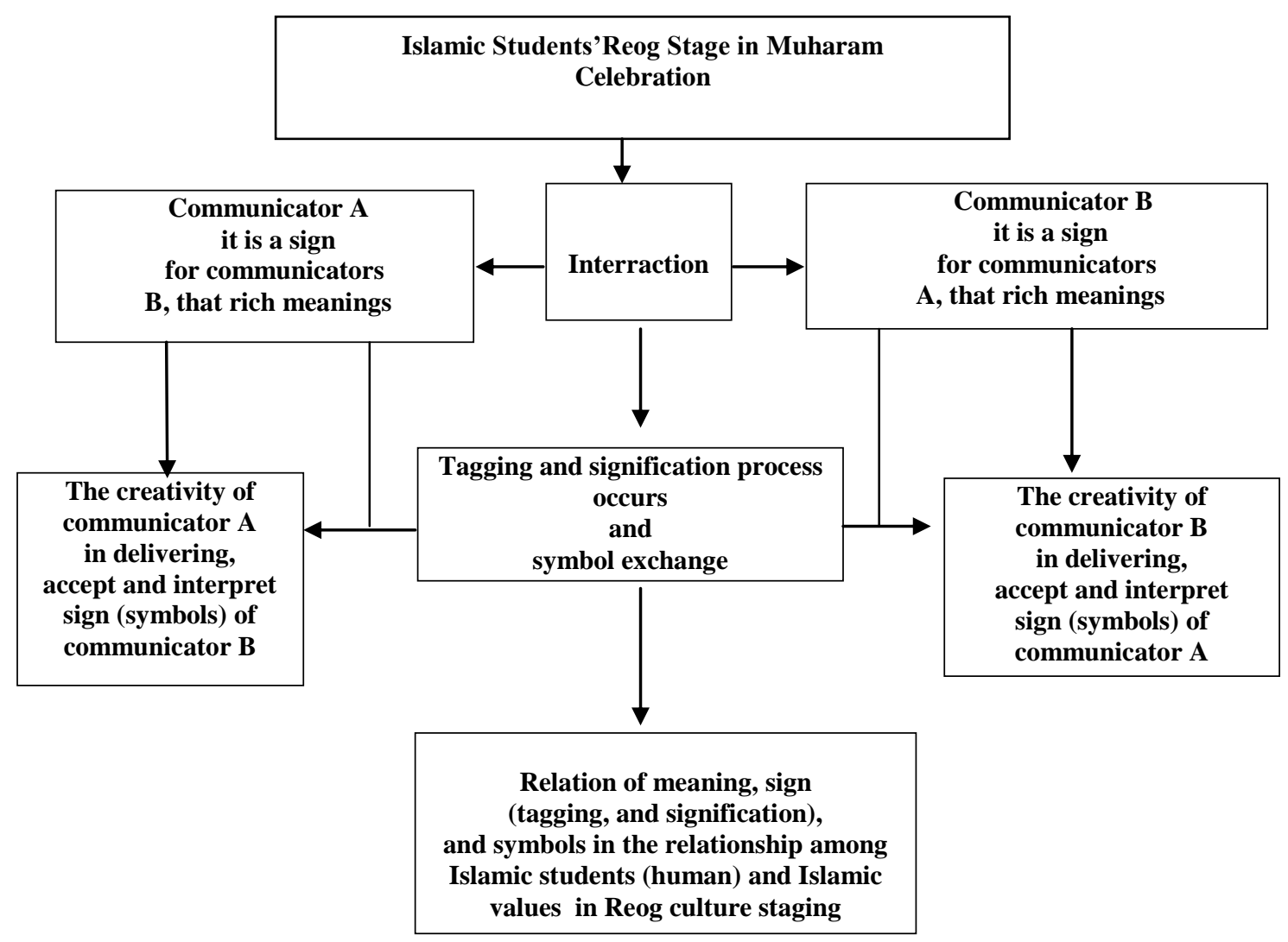

Figure 1. Theoritical Framework of The Research

\section{Method}

This research is a qualitative study. Qualitative research wants to portray social reality in the relationship among humans. The study wanted to illustrate the relationship among students of State Institute for Islamic Studies Ponorogo from tagging and signification aspects of a sign and exchange of symbols. In the end, how tagging, signification, and the exchange of symbols produce meaning.

The method used the interpretation of semiotics and symbolic interactionism. Symbolic interactionism will obtain and understand human behavior from a subjective point of view. Symbolic interactionism is within the positivist school of thought. Using a social psychological vantage point, symbolic interactionism, as explained by members of the Chicago school, specifically by Mead and Thomas, posits that one's self-concept and behavior change from one situation to another. This change depends on the subjects' interpretation of symbols from a given situation and on their generalized interpretation of symbols communicated by others (Hume \& Qi, 2014).

Semiotics is the study of signs and signification, including both linguistic and nonlinguistic signs (Lyne, 2008). Drawing from semiotics and "behavior exchange," rules regulating costs and rewards accruing to the communicators from the relationship 
are shown to be an important part in communication (Pearce \& Sharp, 1973). The functions of the semiotics describe how the relationship among students as signs and processes of tagging and signification, while symbolic interactionism will photograph the relationship among students as a symbol of exchange phenomenon. The informants of this research are students of State Institute for Islamic Students Ponorogo in Reog staging.

Researcher obtains data from informants through interview. In this research, data analysis uses Miles and Huberman procedure. Miles and Huberman proposed three steps for qualitative data analysis such as data reduction, data presentation, and conclusion. This procedure is used to obtain accuracy in data analysis.

\section{Results and Discussions}

Reog Art Staging

Reog is one of the traditional performance art works and is also a folk theater that is usually performed in outdoor processional (Supriadi, 2015). Reog Ponorogo performance art is a tradition of Ponorogo people to attract the attention of the public. This art performance aims to maintain good relationship among people (Mukarromah, 2012).

These dancers depict a brave lion figure. Next is a dance performed by 6 to 8 girls riding horses. In traditional Reog, these dancers are usually played by a 'jathil', a male dancer dressed as a woman. This dance is called 'kepang' or jathilan dance, which must be distinguished by other dance art namely dance of kuda lumping.

Reog and Grebeg Suro is held at 1st day of Muharam. Grebeg Suro's activities consist of several series, ranging from: arts and traditions that show Reog art with festival models followed by various Ponorogo people, then cross-history marches and heirloom (bathing keris with flowers), and Larungan, Sesaji, and Risalah Do'a in Ngebel lake. The celebration of Grebeg Suro is also an indicator of the ponorogo regency government's concern for the socio-economic and cultural problems of ponorogo people. The head of Ponorogo Regency conducts policy making, based on the values that the community believes in, where the region in the past history has local wisdom in the form of organizing Grebeg Suro ritual activities.

Grebeg Suro ritual tradition is culturally a form of public gratitude to the creator for the favors and blessings that have been given and containers to ask for the safety of life. Especially at the Larungan, Sesaji event in Lake Ngebel. However, when viewed from the of community's view, it turns out that the tradition of Grebeg Suro's ritual sparked a different perception among Ponorogo people, for example such as Ponorogo people who live in one of the areas where the Grebeg Suro ritual tradition in Ngebel village with people living in ponorogo such as Gupolo Village, Babadan Sub-District, Ponorogo Regency (Istikharotulkhoirunnisa, 2019). According to Herusasoto, one of the traditions or customs of behavior is the level of cultural value in the form of ideas that 
consistencies the most valuable things in people's lives, and is usually rooted in the emotional and natural parts of the human soul.

Grebeg Suro is very important for the life of the Javanese people, especially Ponorogo because it is an annual event that is celebrated every 1st day of Muharam (1 Suro in Java year) and routine activities aimed at preserving the noble values of the nation's culture, namely the peculiarities and authenticity of Reog which became the original art of Ponorogo. With the annual festival held, all children and foreign countries understand that Reog is Ponorogo's original art. It is also to commemorate and support the arrival of the Islamic new year. The Grebeg Suro Ponorogo procession contains religious and cultural symbolic values. Religious values in the form of expressions of gratitude by doing tirakatan (many remembrances and deeds soleh) and kenduri (safe sharing of sustenance), and establishing inter-citizenship relations. In addition to religious nuances, cultural nuances also the opening Grebeg Suro, namely with the mass Reog dance held in Ponorogo square, Kirab, selection of tourist ambassadors, Larung, Risalah Do'a event and prayer. Each procession equipment contains symbolic meanings to convey cultural messages through the medium of art. In addition to religious values and cultural values, there are still values contained in the tradition of Grebeg Suro.

\section{Muslim Identity of Islamic Students in State Institue for Islamic Studies Ponorogo at} Reog Staging

Islamic students activities heavily influenced by their muslim identity. Most students have learned at Islamic Boarding School. Islamic students in State Institute for Islamic Studies Ponorogo were creative human in interaction each other. Based on interview of interaction in Reog staging activity, can be obtained that the appearance of students in front of other students is a message of signs and symbols rich in meaning. The description of the student's appearance both the symbols of clothing and gestures already appear when the student confronts or sees another student. All student appearances in Reog performance activities are signs and symbols that have meaning. With the background of a muslim, the appearance of a student on the stage Reog Muharam conveys a message of muslim values. Islamic values that emerge such as impression, decency, friendship, and harmony of hijri new year culture and traditional culture Reog Ponorogo. Identity that appears as a muslim student with a polite boarding school background.

More of students in State Institue for Islamic Studies Ponorogo have boarding school background. State Institue for Islamic Studies Ponorogo is one of the islamic religious universities in the majority of Islamic education areas. Students who study on this campus are mostly from boarding schools. Muslim identity that appears in students is Salafist Islam such as students who study in Mayak boarding school, Jenes boarding school, Tebu Ireng boarding school, Lirboyo Boarding School and others. Moderate 
Muslim identity is the identity of students derived from modern boarding school such as Daarussalam Gontor boarding school, Al-Mawaddah, Al-Iman, and others. There are also students with modern muslim identities who come from Wali Songo Ngabar boarding school, Ar-Risalah Slahung boarding school, and others. Students with salaf boarding school backgrounds are on average quieter. Students with modern boarding school backgrounds are more critical.

The background of muslim identity also has an impact on how to dress, gestures, and how to speak. Students with a salaf boarding school background show how to dress more politely. Students with modern boarding school backgrounds show more fashionable way of dressing. With different muslim identities, muslim values such as harmony, friendship, and honesty remain well established.

Tagging and Signification of Inter-student of State Institute for Islamic Studies Ponorogo in Human Relations of Reog Staging Activity

Based on the interview, it can be explained the semiotic function of the linkage of signs, symbols, and meanings as follows:

Firstly, semiotics function in the inter-student's tagging and signification of State Institute for Islamic Studies Ponorogo in Reog staging activity. In the study of semiotics, tagging and signification as a process of the use or the stages in the application of the drug. Signifier and signified ultimately form a sign. Here are the results of interviews among students from the tagging and signification process as meaning process of signs.

Table 1. The relationship among students as the process of tagging and signification as signification process of sign in semiotics

\begin{tabular}{|c|c|c|c|}
\hline \multirow[t]{2}{*}{ Informants } & \multicolumn{2}{|c|}{ Object } & \multirow[t]{2}{*}{ Signs } \\
\hline & Tagging of People faced & Signification of People faced & \\
\hline Digista Heru & Object in front of Digista & Object in front of Digista & Sightings \\
\hline Purnomo & $\begin{array}{l}\text { Girl "Dara Sifa" Friendly, ordinary } \\
\text { greeting, wear college clothes. }\end{array}$ & Friend, Girl, student in class & $\begin{array}{l}\text { of female } \\
\text { student. }\end{array}$ \\
\hline Dara Sifa & $\begin{array}{l}\text { Object in front of Dara Sifa } \\
\text { Men wear Glasses } \\
\text { Strange sighting, Head some what } \\
\text { to the right, Way of a dashed talk. }\end{array}$ & $\begin{array}{l}\text { Object in front of Dara Sifa } \\
\text { Friend, student, strange men } \\
\text { in the class }\end{array}$ & $\begin{array}{l}\text { Sightings } \\
\text { of male } \\
\text { students. }\end{array}$ \\
\hline Binarti & $\begin{array}{l}\text { Object in front of Binarti } \\
\text { a boy Friend, ordinary dress } \\
\text { Student, campus jacket }\end{array}$ & $\begin{array}{l}\text { Object in front of Binarti } \\
\text { Male student friend, } \\
\text { friendly }\end{array}$ & $\begin{array}{l}\text { Sightings } \\
\text { of male } \\
\text { student. }\end{array}$ \\
\hline $\begin{array}{l}\text { Irfan } \\
\text { Wicahyo }\end{array}$ & $\begin{array}{l}\text { Object in front of Irfan Wicahyo } \\
\text { Women uses campus clothes. }\end{array}$ & $\begin{array}{l}\text { Object in front of Irfan } \\
\text { Wicahyo }\end{array}$ & $\begin{array}{l}\text { Sightings } \\
\text { of female }\end{array}$ \\
\hline
\end{tabular}




\begin{tabular}{|c|c|c|c|}
\hline & & $\begin{array}{l}\text { Coed Friends, friendly in } \\
\text { campus, in the same class, } \\
\text { friendly. }\end{array}$ & students. \\
\hline $\begin{array}{l}\text { Muhammad } \\
\text { Sofi } \\
\text { Mubarok }\end{array}$ & $\begin{array}{l}\text { Object in front of Muhammad Sofi } \\
\text { Mubarok } \\
\text { Women uses campus clothes. }\end{array}$ & $\begin{array}{l}\text { Object in front of } \\
\text { Muhammad Sofi Mubarok } \\
\text { Coed Friends, friendly in } \\
\text { campus, friendly. }\end{array}$ & $\begin{array}{l}\text { Sightings } \\
\text { of female } \\
\text { student. }\end{array}$ \\
\hline $\begin{array}{l}\text { Maya Putri } \\
\text { Damayanti }\end{array}$ & $\begin{array}{l}\text { Object in front of Maya Putri } \\
\text { Damayanti } \\
\text { a boy Friend, ordinary dress } \\
\text { Student, campus jacket. }\end{array}$ & $\begin{array}{l}\text { Object in front of Maya } \\
\text { Putri Damayanti male } \\
\text { student friend, friendly }\end{array}$ & $\begin{array}{l}\text { Sightings } \\
\text { of male } \\
\text { student. }\end{array}$ \\
\hline
\end{tabular}

Path of logical thinking taken (conclusion):

Tagging and signification of students relations is the process of meaning of a sign. Signifier and Signified make sign.

Source : Researcher'analysis about students'interview

From the table above, it can be described that Digista Heru Purnomo face to face with Dara Sifa, then appearance of Digista Heru Purnomo in the eyes of Dara Sifa as a sign that will form a visual image (tagging) and mental concepts (signification) about Digista Heru Purnomo. On the other side, the performance of Dara Sifa in front of Digista Heru Purnomo was a sign and it created form a visual image (tagging) and mental concepts (signification) about Dara Sifa. The appearance of Binarti and Irfan Wicahyo When the two come face-to-face, then each of these communicators as a sign in the eyes of both. Each communicator that is a sign will also form a visual image (tagging) and mental concepts (signification) about each communicator.

In the same as about Muhammad Sofi and Maya Putri Damayanti. Based on explanation above, the interaction of inter-students can be described as tagging and signification of students relations is the process of meaning of sign. Signifier and signified make sign.

Secondly, symbolic interactionism's function in tagging and signification across college students in State Institute for Islamic Studies Ponorogo in Reog staging activity. In the study of symbolic interactionism, tagging and signification in the relationship among Islamic students of State Institute for Islamic Studies Ponorogo in Reog staging activity is an exchange of symbols to get a sense of meaning so that the relationship among Islamic students is meaningful. The following is the result of interviewing among students as a tagging process and a signification which is also a symbol exchange. 
Table 2. The relationship among Islamic students as the process of tagging and signification as symbol exchanges in symbolic interactionism

\begin{tabular}{|c|c|c|c|}
\hline \multirow[t]{2}{*}{ Informants } & Tagging the person faced. & $\begin{array}{l}\text { Signification the person } \\
\text { faced. }\end{array}$ & \multirow{2}{*}{$\begin{array}{l}\text { Meaningful } \\
\text { symbol } \\
\text { exchanges. }\end{array}$} \\
\hline & \multicolumn{2}{|c|}{$\begin{array}{l}\text { Signs (Include symbol) } \\
\text { the person faced. }\end{array}$} & \\
\hline $\begin{array}{l}\text { Digista Heru } \\
\text { Purnomo }\end{array}$ & $\begin{array}{l}\text { Object in front of Digista } \\
\text { Woman Dara Sifa, friendly, } \\
\text { Ordinary greeting }\end{array}$ & $\begin{array}{l}\text { Object in front of Digista } \\
\text { Girl student is in the class. }\end{array}$ & \multirow{2}{*}{$\begin{array}{l}\text { Exchange of } \\
\text { Symbol people } \\
\text { As a symbol } \\
\text { of friendly } \\
\text { coed women } \\
\text { and male } \\
\text { symbols of } \\
\text { unique } \\
\text { students. The } \\
\text { meaning of } \\
\text { campus male } \\
\text { students and } \\
\text { female } \\
\text { student, near } \\
\text { friends } \\
\text { (friendly). }\end{array}$} \\
\hline Dara Sifa & $\begin{array}{l}\text { Object in front of Dara Sifa } \\
\text { Student uses Glasses, strange } \\
\text { Sightings, head some what to } \\
\text { the right way of the dashed } \\
\text { talk. }\end{array}$ & $\begin{array}{l}\text { Object in front of Dara Sifa } \\
\text { Strange student in the class. }\end{array}$ & \\
\hline Binarti & $\begin{array}{l}\text { Object in front of Binarti } \\
\text { Regular male friend wear } \\
\text { student dress, campus jacket, } \\
\text { relax and joking. }\end{array}$ & $\begin{array}{l}\text { Object in front of Binarti } \\
\text { Male student Friend, } \\
\text { friendly }\end{array}$ & \multirow{2}{*}{$\begin{array}{l}\text { Exchange of } \\
\text { Symbol people } \\
\text { as a symbol of } \\
\text { female } \\
\text { friendly coed, } \\
\text { Cheerful and } \\
\text { male symbol } \\
\text { of near student } \\
\text { likes Joking }\end{array}$} \\
\hline Irfan Wicahyo & $\begin{array}{l}\text { Object in front of Irfan } \\
\text { Wicahyo } \\
\text { Cheerful Friendly woman } \\
\text { uses campus jacket. }\end{array}$ & $\begin{array}{l}\text { Objek in front of Irfan } \\
\text { Wicahyo } \\
\text { Intimate Coed Friends in } \\
\text { campus in the same class, } \\
\text { friendly. }\end{array}$ & \\
\hline $\begin{array}{l}\text { Muhammad } \\
\text { Sofi Mubarok }\end{array}$ & $\begin{array}{l}\text { Object in front of } \\
\text { Muhammad Sofi } \\
\text { Woman Maya Putri } \\
\text { Damatanti, friendly, Ordinary } \\
\text { greeting }\end{array}$ & $\begin{array}{l}\text { Objek in front of } \\
\text { Muhammad Sofi } \\
\text { Intimate Coed Friends in } \\
\text { campus, friendly. }\end{array}$ & \multirow{2}{*}{$\begin{array}{l}\text { Exchange of } \\
\text { Symbol people } \\
\text { as a symbol of } \\
\text { female } \\
\text { friendly coed, } \\
\text { Cheerful and } \\
\text { male symbol } \\
\text { of near student }\end{array}$} \\
\hline $\begin{array}{l}\text { Maya Putri } \\
\text { Damayanti }\end{array}$ & $\begin{array}{l}\text { Object in front of Maya Putri } \\
\text { Damayanti } \\
\text { Regular male friend wear } \\
\text { student dress, campus jacket, } \\
\text { relax and joking. }\end{array}$ & $\begin{array}{l}\text { Object in front of Maya } \\
\text { Putri Damayanti } \\
\text { Male student Friend, } \\
\text { friendly }\end{array}$ & \\
\hline
\end{tabular}


Path of logical thinking taken (conclusion):

Tagging and signification is a sign of a symbol exchange for meaning in the relationship among people.

Source : Researcher'analysis about students'interview

The table above is described as follows. While Digista Heru Purnomo faced to face with Dara Sifa, then Digista Heru Purnomo as sign. In the view of Charles Shander Pierce, a sign can be an icon, an index, and a symbol. While Digista Heru Purnomo faced to face with Dara Sifa, then his appearance in front of Dara Sifa as a sign and symbol category in the eyes of Dara Sifa. So does the appearance Dara Sifa in the eyes Digista Heru Purnomo as a sign and symbol category for Digista Heru Purnomo. So does Binarti's appearance in the eyes of Irfan Wicahyo and Irfan Wicahyo's appearance in Binarti's eyes. In the end the process of tagging and signification of each communicator to each other which is a sign of the essence is an exchange of symbols and forming a perception or meaning in each communicator. In the same as about Muhammad Sofi and Maya Putri Damayanti. Based on explanation above, the interaction of interstudents can be described as tagging and signification is a sign of a symbol exchange for meaning in the relationship among people.

Thirdly, symbolic interactionism and semiotic's functions in the tagging and signification across student of State Institute for Islamic Studies Ponorogo in Reog staging activity. Based on the semiotics glass and the symbolic interactionism, interaction among students on top, the use of the following is a proposition. From the function of semiotics relationship among Islamic students in Reog staging activity can shows proposition construction of the packaging: "Tagging and Signification in relation across student is the meaning process of the use of a sign. Tagging and signification form sign." From the symbolic interactionism function, interaction among Islamic students in Reog staging activity gained the construction proposition of the packaging: "Tagging and signification about sign is the exchange of symbols to derive meaning in the relationship among Islamic students (human)."

Fourtly, the function of the integration of symbolic interactionism and semiotics (mixmethodology) in the linking of tagging and signification were a sign and symbols exchange among Islamic Students of State Institute for Islamic Studies Ponorogo in Reog staging activity.

Based on the functions of symbolic interactionism and semiotic in the tagging and signification of a sign of the relationship among students of State Institute for Islamic Studies Ponorogo in Reog staging activity as follows: firstly, proposition of construction of first degree interpretation can be described as relations among humans is a tagging and signification of a sign that is an exchange of symbols among people who are related. Secondly, proposition of the construction of the second degree of meaning can be described as criteria for relationships, tagging and signification, and the 
exchange of symbols are symptoms of interactions or relationships among human. This whole criterion is another term for the criteria in the process of mutual understanding of meaning and mutual understanding of meaning is identical to communication. The essence of communication is meaning.

Thirdly, proposition of third degree construction meaning can be described as the criteria for relations, tagging and signification, and the exchange of symbols are symptoms of interactions or relationships among human and these criteria can explain the process or what is communication.

Fourtly, proposition of construction of the fourth degree of significance can be described as communication is the process of tagging and signification of a sign in the exchange of signs or symbols to obtain mutual understanding of meaning. Fifthly, proposition of construction of fifth degree significance can be described as communication is the process of tagging and signification on symbols (signs) to obtain mutual understanding of meaning. And Finally, logical thoughts are drawn (conclusions) can be described as communication is the process of tagging and signification on symbols (signs) to obtain a mutual understanding of meaning that involves human creativity in the production, exchange, and meaning process of the sign or symbol.

The values contained in the Reog staging at Grebeg Suro Muharam's commemoration are the integration between Reog cultural values and Islamic such as leadership, togetherness, and mutual respect for different cultures. The staging of Reog as a means of silaturrahmi in Ponorogo community.

\section{Conclusion}

The interrelationship of meaning, signs, and symbols in the relationships among Islamic students is obtained by propositions of meaning construction can be described through two points of view such semiotic approach and symbolic interactionism. For instance, semiotic approach assumed that tagging and signification in relation across Islamic student in Reog culture staging is the meaning process of the use of a sign. Tagging and signification form sign. Meanwhile, symbolic interactionism saw tagging and signification about sign is the exchange of symbols to derive meaning in the relationship among Islamic students (human). Interaction between players on the Reog stage forms togetherness, soul sacrifice, struggle, and friendship. The identities that appear in Reog players include salafi muslim students and moderate muslim students. Students with salaf muslim identity with salaf boarding school background such as Mayak Boarding School, Jenes Boarding School, Tebu Ireng Boarding School, Lirboyo Boarding School, and others. Students with moderate muslim identity with modern boarding school background such as Darussalam Gontor Boarding School, Al-Iman Boarding School, Ar-Risalah Boarding School, Wali Songo Ngabar Boarding School, and others. Students with Salafi muslim identities dress as they are, quiet, and polite. 
Students with moderate muslim identities are fashionable, more critical, and modern. The Islamic values that students build in the staging of Reog in Muharam include harmony, friendship, silaturrahmi, and manners. The others values are leadership, togetherness, and mutual respect for different cultures.

\section{References}

Block, E. (2013). A Culturalist Approach to the Concept of the Mediatization of Politics: The Age of 'Media Hegemony'. Communication Theory, 23 (3), 259-78. Retrieved https://doi.org/10.1111/comt.12016.

Bourdon, J. (2018). The Case for the Technological Comparison in Communication History. Communication Theory, 28 (1), 89-109. Retrieved from https://doi.org/10.1093/ct/qtx001.

Fuchs, C. (2019). Henri Lefebvre's Theory of the Production of Space and the Critical Theory of Communication. Communication Theory, 29 (2), 129-50. Retrieved from https://doi.org/10.1093/ct/qty025.

Gallant, A. (2014). Symbolic Interactions and the Development of Women Leaders in Higher Education: Symbolic Interactions and Development of Women Leaders In HE. Gender, Work \& Organization, 21 (3), 203-16. Retrieved from https://doi.org/10.1111/gwao.12030.

Hume, W.M \& Qi, Z. (2014). Symbolic Interactionism. The International Encyclopedia of Communication. Retrived from https://doi.org/10.1002/9781118517390.wbetc100

Istikharotulkhoirunnisa. (2019). Persepsi Masyarakat Terhadap Tradisi Ritual Grebeg Suro Di Ponorogo. https://www.kompasiana.com /istikharotulkhoirunnisa/ 5cbfdd f2cc528307cc69d232/

Jenkins, D. H. (1961). Prediction in Interpersonal Communication. Journal of Communication, 11 (3), 129-35. Retrieved from https://doi.org/10.1111/j.14602466.1961.tb00342.x.

Jensen, K. B. (2013). Definitive and Sensitizing Conceptualizations of Mediatization. Communication Theory, 23(3), 203-222. Retrieved from https://doi.org/10.1111/comt.12014

Kencanasari, L.S. (2019). Warok Dalam Sejarah Kesenian Reog Ponorogo (Warok in the History of Art Reog Ponorogo). Jurnal Filsafat 19 (2). 180-198. Retrieved from https://doi.org/10.22146/jf.3446

Lyne, J. (2008). Rhetoric and Semiotics. The International Encyclopedia of Communication, Retrieved from https://doi.org/10.1002/9781405186407.wbiecr077

Mukarromah, S. \& Devi, S. (2012), Mobilisasi Massa Partai melalui Seni Pertunjukan Reog di Ponorogo tahun 1950-1980, Jurnal Verleden 1(1) Retrieved from http://journal.unair.ac.id/downloadfull/VERLEDEN4259-

810f9a2e3dfullabstract.pdf 
Pearce, W.B \& Sharp, S.M (1973). Self-Disclosing Communication. The International Encyclopedia of Communication. Retrieved from https://doi.org/10.1111/j.14602466.1973.tb00958.x

Ritchie, L. D \& Leslie T. G. (1989). Communication as a Symbolic Activity. Journal of Communication, 39 (4), 121-26. Retrieved from https://doi.org/10.1111/j.14602466.1989.tb01056.x.

Sigismondi, P. (2018). Exploring Translation Gaps: The Untranslatability and Global Diffusion of 'Cool'. Communication Theory, 28 (3), 292-310. Retrieved from https://doi.org/10.1093/ct/qtx007.

Supriadi, W. (2015). Regenerasi Seniman Reog Ponorogo untuk Mendukung Revitalisasi Seni Pertunjukan Tradisional dan Menunjang Pembangunan Industri Kreatif. Cakra Wisata, 16 (1), 13-22. Retrieved from https://jurnal.uns.ac.id/cakrawisata/article/view/34468/22623

Stewart, D. K. (1966). Signs, Symbols, and Meaning. Journal of Communication, 16 (1), 4-9. Retrieved from https://doi.org/10.1111/j.1460-2466.1966.tb00012.x.

Thomas, P. N. (2020), The Imperialism of Categories: Concepts and Contexts in Communication for Social Change. Communication Theory, 30(4), 388-406. Retrieved from https://doi.org/10.1093/ct/qtz026

Wee, L. (2006). The Semiotics of Language Ideologies in Singapore1. Journal of Sociolinguistics, 10 (3), 344-61. Retrieved from https://doi.org/10.1111/j.13606441.2006.00331.x. 